\title{
Status of Soil Properties Under Canopy of Farmers' Preferred Coffee Shade Tree Species, in Adola Rede District, Guji Zone, Southern Ethiopia
}

\author{
AschalewEmire', Zebene Asfaw ${ }^{2}$ \\ ${ }^{1}$ Oromia Agricultural Research Institute, Bore Agricultural Research Center, Bore, Ethiopia \\ ${ }^{2}$ Hawassa University, Wondogenet College of Forestry and Natural Resources, Shashemane, Ethiopia
}

Email address:

aschu1511@gmail.com (A. Emire), zebeneasfaw@yahoo.co.uk (Z. Asfaw)

\section{To cite this article:}

Aschalew Emire, Zebene Asfaw. Status of Soil Properties Under Canopy of Farmers' Preferred Coffee Shade Tree Species, in Adola Rede District, Guji Zone, Southern Ethiopia. American Journal of Agriculture and Forestry.Vol. 6, No. 5, 2018, pp. 148-155.

doi: 10.11648/j.ajaf.20180605.15

Received: June27, 2018; Accepted: September10, 2018; Published: October13, 2018

\begin{abstract}
The study was conducted at Adola Rede District, in Guji Zone, Southern Ethiopia. The aim of the study was to investigate farmers' preference criteria of soil fertility improving shade tree species and to identify Status of soil properties under canopy of farmers' preferred shade tree species. To address the objectives of this study, all necessary data were collected through key informant interview, questionnaire survey and soil sampling. A total of 20 key informants and 90 households were participated for household interview. Based on their selection criteria, sampled households have done preference ranking of shade tree species used for soil fertility enhancement. The results of this study showed that, farmers' main selection criteria were based on decomposition rate of shade tree litter fall, soil moisture status under shade tree canopy, coffee yield increments and growth rate of coffee plants under shade tree canopy. Generally, the preference ranking of key informants and respondent households soil fertility improving coffee shade tree species were in the order of: Ficus sur $>$ Cordia africana $>$ Millettia ferruginia $>$ Albizia gummifera $>$ croton macrostachyus $>$ Acacia abyssinica. From the identified soil fertility improving coffee shade tree species, soil samples were taken from under canopy of Ficus sur with $1^{\text {st }}$ rank and Cordia africana with $2^{\text {nd }}$ rank farmers' preferences. For soil analysis from under canopy of both coffee shade trees and from outside the tree canopy, a total of 48 soil samples were taken. The results of soil properties under canopy of both shade trees showed that SOC, total N, available $\mathrm{P}$, exchangeable $\mathrm{K}, \mathrm{CEC}$ and soil $\mathrm{pH}$ were significantly $(\mathrm{P}<0.05)$ higher than outside the tree canopy. The results of $\mathrm{BD}$ outside the tree canopy was significantly $(\mathrm{P}<0.05)$ higher than under canopy of both coffee shade trees. However, soil textures under canopy of both coffee shade trees and outside the tree canopy was not significantly different. Based on the finding of this study, status of soil fertility under canopy of Ficus sur was significantly $(\mathrm{P}<0.05)$ higher than Cordia africana. Thus, the soil laboratory analyzed results of soil physico-chemical properties are in agreement with farmers' rank of coffee shade tree preferences. Therefore, the findings suggest that if knowledge of local farmers is recorded and effectively used with scientific findings, it can provide valuable information. Moreover, for soil fertility enhancement and increments of coffee production incorporation of the two shade trees in coffee farms of similar agro-ecological conditions is paramount.
\end{abstract}

Keywords: Coffee Growers, Coffee Shade Tree Species, Soil Fertility Improving, Cordia africana, Ficus sur

\section{Introduction}

Trees can improve the nutrient balance of soil by reducing unproductive nutrient losses from erosion and leaching and by increasing nutrient inputs through nitrogen fixation and increased biological activities by providing biomass and suitable microclimate [1]. The presence of strips of different tree species within agricultural fields has been associated with increases in soil carbon, soil nitrogen, enzyme activity and as well as an increase presence of a soil structure features that inhibits erosion [2]. Shade tree species play an important role in erosion control because they protect the soil against raindrop impact; reduce runoff velocity by increasing surface roughness and water infiltration as well as providing a litter 
layer and tree roots that create channels in the soil [3]. Growing shade trees with different crops as well reduce land degradation and improve recycling of nutrients, while producing fuel wood, fodder, fruits and timber in addition to products from annual crops [4].

In coffee agroforestry systems the benefits of shade trees for soil and water conservation are well-recognized. Shade tree root systems hold soil in place and create large pore space for increased infiltration. Shade tree leaves and other organic debris provide soil cover to reduce rainfall impact, minimizing run off, erosion and anchoring soil in place [5]. Shade tree species protect the soil from adverse insolation, help maintain soil organic matter, reduce evaporation from soil, and retain soil productivity. The mixture of leaf litter from different species (such as crop and shade trees) as well affects the decomposer community structure, and the litter decay and associated nutrient fluxes to the soil [6].

Nitrogen fixing shade tree species fix sufficient nitrogen to meet current and potentially increasing $\mathrm{N}$ needs of woody perennial crops, including coffee. Management practices, such as green pruning, elevate nitrogen fixation levels and serve to maximize fixation rates. From the nitrogen that is fixed, it can make its way to the crop through a number of different pathways, which includes: decomposition and mineralization of donor organic matter [7]. The cycling of nutrients in shade plantations is enhanced by the presence of shade tree species. Particularly, natural litter fall and shade management practices, such as pruning of tree branches, have a critical influence on nutrient transfer from tree to soil, provided that the pruned branches are left on the farm. Thus nutrient turnover and the transfer of $\mathrm{N}, \mathrm{P}, \mathrm{K}, \mathrm{Ca}$, and $\mathrm{Mg}$ to the soil are greater in shaded plantations [8].

The study site is one of the potential coffee producing Districts in Guji zone of Oromia Regional State, Southern Ethiopia. Moreover, coffee growers' of the study District have the trend of cultivating coffee plants under the shade of natural forest canopy and under plantation shade tree covers. However, in Adola Rede District information about farmers' preferences of soil fertility improving shade tree species and Status of Soil properties under canopy of soil fertility improving shade tree species of the study site is not so far studied. Therefore, this study was conducted to i) Identify soil fertility improving shade tree species of the study District based on farmers' preference criteria and iii) to identify status of soil properties under canopy of farmers' preferred shade tree species of the study District.

\section{Material and Methods}

\subsection{Description of the Study Area}

The study was conducted in Adola Rede District of Oromia Regional State, in Southern part of Ethiopia, located at $475 \mathrm{~km}$ south of Addis Ababa(Figure 1).It is situated between $5^{\circ} 44^{\prime} 10^{\prime \prime}$ - $6^{\circ} 12^{\prime} 38^{\prime \prime}$ North latitude and 38 $45^{\prime} 10^{\prime \prime}$ $39^{\circ} 12^{\prime} 37^{\prime \prime}$ East longitude at an elevation of 1500-2000 meters above sea level. The mean annual maximum and minimum temperature of the study District is $23^{\circ} \mathrm{C}$ and $16^{\circ}$ Crespectively. The study District has bimodal rainy seasons, summer from June to November and spring from March to May. The total area of the study District is $1401 \mathrm{~km}^{2}$. From the total area of the study District, $33 \%$ is cultivation land, $30 \%$ is pasture land, $20 \%$ is forest land and the remaining $17 \%$ is considered as swampy or degraded land [9].The total population of Adola Rede District is 583,816 and the livelihoods of the inhabitants are depending on mixed farming, coffee production and semi-nomadic economic activities [10]. The study District is well known with its important agricultural cash crops such as maize, wheat, barley, teff, lentils, chick pea, field pea, haricot beans, sweat potato, chat, Enset and coffee production [9].

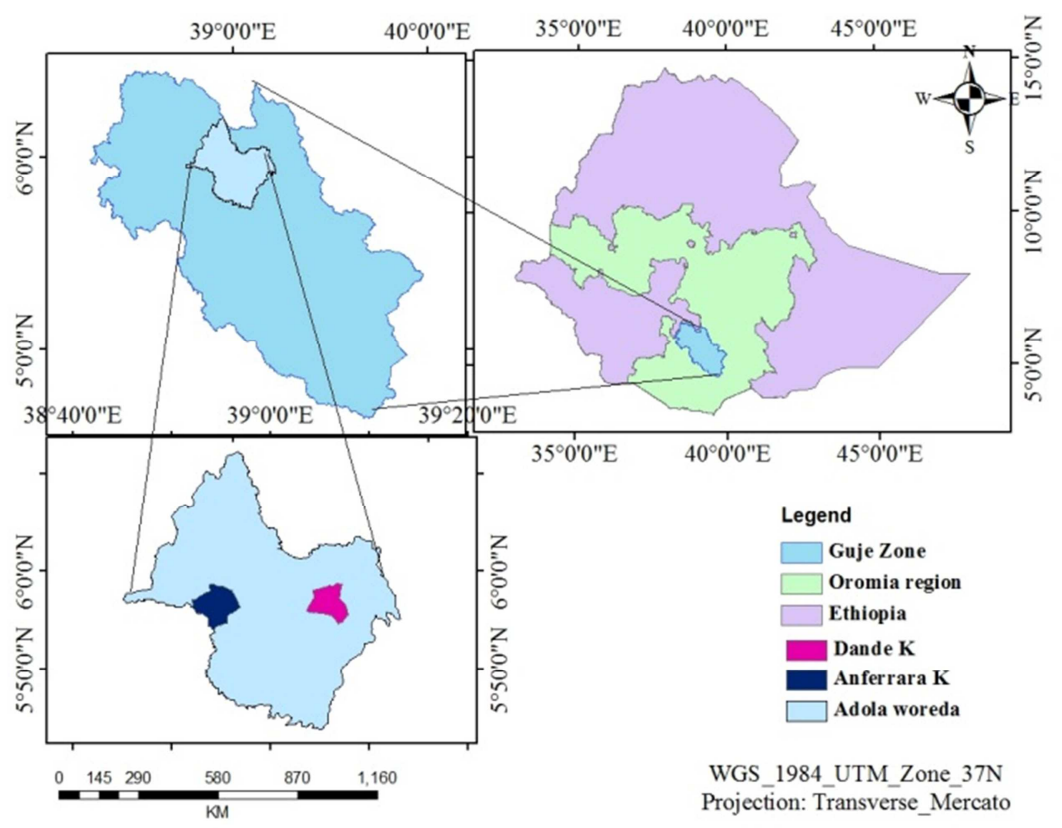

Figure 1. A map of showing the study site. 


\subsection{Data Collection Methods}

The various data collection tools employed were key informant interview to collect mainly qualitative information about soil fertility improving coffee shade tree species. The household survey was used to collect mainly detailed quantitative data about farmers' local knowledge on preference criteria of soil fertility improving shade tree species either planted or retained on their farms. The last data collection methods is soil sampling under the canopy of farmers preferred coffee shade tree species.

\subsubsection{Key Informant and Household Interview}

A total of 20 key informants were selected and used for this study. The necessary information collected from key informants was later used for developing questionnaires for household interview. For household interview, a total of 90 respondents were randomly selected for the questionnaire interview from the study District. Those selected respondent households have done preference ranking of soil fertility improving shade tree species based on their selection criteria.

\subsubsection{Tree Selection}

From identified shade tree species commonly used for shading coffee plants in coffee growers' fields of the study District, farmers' have done preference ranking of shade tree species used for soil fertility enhancement. Based on their preferences, Ficus sur with $1^{\text {st }}$ rank and Cordia africana with $2^{\text {nd }}$ rank were selected for this study. For soil sampling, Ficus sur coffee shade trees with relatively similar management practice, similar age, Height, DBH and Crown diameter were first identified (Table 1).

Similar procedure was followed for selecting Cordia africana coffee shade trees at each study site. Totally 24 (six tree at each study site) were selected for soil sampling. Then soil samples were taken from under canopy of Ficus sur and Cordia africana coffee shade tree species.

Table 1. Age, Height, DBH and Crown diameter of selected Ficus sur and Cordia africana coffee shade tree species.

\begin{tabular}{|c|c|c|c|c|c|c|}
\hline Study site & Shade tree species & Tree no. & Age & Height(m) & DBH(m) & Crown Diameter(m) \\
\hline Anferara & Ficus sur & 1 & 27 & 15 & 45 & 7 \\
\hline ” & , & 2 & 26 & 15.5 & 46 & 6 \\
\hline$"$ & , & 3 & 30 & 17 & 44.5 & 6.5 \\
\hline \multirow[t]{2}{*}{$"$} & ,, & 4 & 28 & 16.5 & 43 & 6.4 \\
\hline & , & 5 & 27 & 17 & 47 & 7.2 \\
\hline \multirow[t]{2}{*}{ " } & Ficus sur & 6 & 31 & 16 & 45 & 5.8 \\
\hline & & Mean & 28.2 & 14.5 & 45.1 & 6.5 \\
\hline ", & Cordia africana & 1 & 20 & 14.5 & 36 & 5 \\
\hline$"$ & , & 2 & 24 & 15 & 35 & 5.5 \\
\hline , & , & 3 & 25 & 16 & 35 & 5 \\
\hline 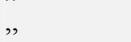 & , & 4 & 22 & 15.5 & 39 & 6 \\
\hline 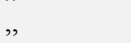 & , & 5 & 24 & 16 & 40 & 6.2 \\
\hline \multirow[t]{2}{*}{ Anferara } & Cordia africana & 6 & 21 & 16 & 39 & 6.8 \\
\hline & & Mean & 22.6 & 15.5 & 37.3 & 5.75 \\
\hline Dande & Ficus sur & 1 & 25 & 14 & 48 & 6.4 \\
\hline$״$ & 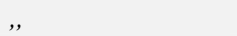 & 2 & 24 & 16.8 & 47 & 7.4 \\
\hline , & ,, & 3 & 26 & 17 & 44.5 & 6.8 \\
\hline , & ,", & 4 & 26 & 15 & 46 & 6.6 \\
\hline 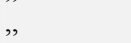 & , & 5 & 29 & 15.6 & 46.5 & 7.2 \\
\hline \multirow[t]{2}{*}{$"$} & Ficus sur & 6 & 30 & 14.6 & 47 & 6.6 \\
\hline & & Mean & 26.6 & 15.6 & 44.8 & 6.8 \\
\hline , & Cordia africana & 1 & 23 & 15 & 36 & 6.6 \\
\hline , & , & 2 & 22 & 15 & 36.4 & 6.4 \\
\hline , & ,, & 3 & 23 & 16.4 & 37 & 5.8 \\
\hline " & ,, & 4 & 25 & 16.5 & 37.4 & 6.2 \\
\hline , & , & 5 & 25 & 15.3 & 37.6 & 6 \\
\hline \multirow[t]{2}{*}{ Dande } & Cordia africana & 6 & 26 & 15.4 & 36.6 & 6.4 \\
\hline & & Mean & 24 & 15.6 & 36.8 & 6.2 \\
\hline
\end{tabular}

\section{Source: From survey result, 2014/2015}

\subsubsection{Soil Sampling and Analysis}

The soil samples under canopies of Ficus sur and Cordia africana coffee shade tree species were taken from surface soil at one depth $(0-15 \mathrm{~cm})$ in four different directions to obtain a composite representative soil sample by following standard procedure. The soil samples taken at $15 \mathrm{~m}$ distance served as a control representing areas beyond the relative influence of the shade tree canopy. Soil samples collected under canopy of each individual tree at each study site was subjected to thorough mixing and taking half heap repeatedly to get composite sample.
In this way, soil samples were collected from under canopy 12 trees of each shade tree. In general, 24 soil samples from under canopy of both shade trees and 24 soil samples from outside the tree canopy were collected. Finally a total of 48 soil samples were taken for soil laboratory analysis. The collected soil samples were air dried, mixed well and passed through a $2 \mathrm{~mm}$ soil sieve to prepare for soil laboratory analysis. The soil laboratory analysis was done for selected physical and chemical soil properties and conducted using the standard procedures. 


\subsubsection{Data Analysis}

The soil laboratory results of selected soil physicochemical properties were coded and entered into Microsoft Office Excel sheet. After organizing the data, the analysis was performed by using Statistical Analysis System (SAS version 9). A two-way analysis of variance (ANOVA) was then performed to compare the status of soil properties under canopy of both selected shade trees and with their respective open area.

\section{Result and Discussion}

\subsection{Farmers' Preference Criteria of Soil Fertility Improving Coffee Shade Trees}

Coffee growers' in the study site have ability to identify coffee shade tree species used for soil fertility improvement. Their main criteria were based on decomposition rate of shade tree litter fall as mentioned by $22.5 \%$ of the households and shade trees that maintain soil moisture under their canopy is considered by $15 \%$ of the respondents as an attribute. Whereas, $37.5 \%$ and $25 \%$ of the households consider coffee yield increments and growth rate of coffee plants as selection criteria of soil fertility improving shade tree species respectively. In general the preference ranking of key informants and respondent households were in the order of: Ficus sur $>$ Cordia africana $>$ Millettia ferruginia $>$ Albizia gummifera $>$ croton macrostachyus $>$ Acacia abyssinica.

\subsection{Soil Physical and Chemical Properties UnderCanopy of Selected Coffee Shade Trees}

As indicated in section 3.1 above coffee growers 'in the study site have long term experience and inherited local knowledge, in managing coffee shade trees for soil fertility improvement. Based on the finding of this study, Ficus sur and Cordia africana were found to be the most preferred coffee shade tree species for sol fertility improvement respectively. This section presents results of laboratory analysis for selected soil physical and chemical properties under and away from the canopy of Ficus sur and Cordia africana coffee shade tree species.

\subsubsection{Soil Physical Properties}

(1) Soil texture

Soil texture, as a factor that might affect soil physicochemical and to some extent soil biological properties, was not significantly affected by the main effects of shade tree species and distance from the shade tree canopy. As the results of textural analysis revealed that, there was no significant difference in the mean proportions of sand, silt and clay between the soils under canopy of both shade trees and with their respective open areas (Table 2). Therefore, the soils are texturally similar and categorized under sandy clay loam. This might be due to the soils have been derived from the same parent material, under the same climate, similar topography and vegetation cover. Moreover, if there was not any difference in soil texture between the soils under canopy of both shade trees and outside the shade tree canopies, it might be due to the effects of coffee shade trees on the soil fertility, rather than to mineralogical or textural differences between the soils. This finding was supported by $[11,12,13]$ who reported that non- significant difference in soil texture under the canopies of Milletia ferruginia, Cordia africana and Eucalyptus camaldulensis as compared to outside the tree canopies. This finding was also in agreement with [14] who reported that non- significant variation in soil texture under the canopies of Balanites aegyptiaca, Accacia tortolis and Accacia seyalas as compared to outside the tree canopies.

Table 2. Mean values of soil textural properties and BD in the surface $(0-15 \mathrm{~cm})$ soils from under and away from the canopy of Ficus sur and Cordia africana coffee shade trees at Adola Rede District, in Guji zone, Southern Ethiopia.

\begin{tabular}{|c|c|c|c|c|c|}
\hline \multirow{2}{*}{ Shade tree species } & \multirow{2}{*}{ Sampletype } & Sand\% & Silt\% & Clay\% & $\mathrm{BD}\left(\mathrm{gm} / \mathrm{cm}^{3}\right)$ \\
\hline & & Mean(Std) & Mean(Std) & Mean(Std) & Mean(Std) \\
\hline Ficus sur & Under canopy & $43.44^{\mathrm{a}} \pm 5.82$ & $30.66^{\mathrm{a}} \pm 2.77$ & $25.66^{\mathrm{a}} \pm 3.49$ & $0.38^{\mathrm{a}} \pm 0.13$ \\
\hline Cordia africana & Under canopy & $42.42^{\mathrm{a}} \pm 6.64$ & $30.08^{\mathrm{a}} \pm 2.91$ & $26.41^{\mathrm{a}} \pm 4.12$ & $0.62^{\mathrm{b}} \pm 0.19$ \\
\hline 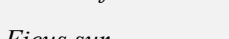 & Under canopy & $43.44^{\mathrm{a}} \pm 5.82$ & $30.66^{\mathrm{a}} \pm 2.77$ & $25.66^{\mathrm{a}} \pm 3.49$ & $0.38^{\mathrm{a}} \pm 0.13$ \\
\hline Flcus sur & Open area & $42.75^{\mathrm{a}} \pm 5.48$ & $32.66^{\mathrm{a}} \pm 3.49$ & $24.58^{\mathrm{a}} \pm 2.43$ & $0.85^{\mathrm{b}} \pm 0.38$ \\
\hline & Under canopy & $42.42^{\mathrm{a}} \pm 6.64$ & $30.08^{\mathrm{a}} \pm 2.91$ & $26.41^{\mathrm{a}} \pm 4.12$ & $0.62^{\mathrm{a}} \pm 0.19$ \\
\hline Cordia africana & Open area & $41.83^{\mathrm{a}} \pm 7.21$ & $29.85^{\mathrm{a}} \pm 4.71$ & $25.54^{\mathrm{a}} \pm 4.35$ & $0.99^{\mathrm{b}} \pm 0.28$ \\
\hline
\end{tabular}

*Within column, soil parameters Means followed by the same letters are not significantly different.

*Within column, soil parameters Means followed by different letters are significantly different.

(2) Soil Bulk density (BD)

Soil BD was significantly affected by main factors of coffee shade tree species and distance from the shade tree canopy. Soil BD outside the shade tree canopy was significantly higher $(\mathrm{P}<0.05)$ than under canopies of Ficus sur and Cordia africana coffee shade tree species. The mean BD under canopies of Ficus sur and Cordia africana as compared to outside the shade tree canopy was increased from $0.38 \mathrm{gm} / \mathrm{cm}^{3}$ to $0.85 \mathrm{gm} / \mathrm{cm}^{3}$ and $0.62 \mathrm{gm} / \mathrm{cm}^{3}$ to $0.99 \mathrm{gm} / \mathrm{cm}^{3}$ respectively (Table 2). The lower BD under canopies of both coffee shade tree species are probably due to the effect of litter fall addition to soil under shade tree canopy, which has resulted in organic matter build-up in soil under shade tree canopy relative to levels in soil outside the shade tree canopy. The lower BD observed under shade tree canopy than in the open areas could be attributed to shade tree canopy that protect the soil from the force of raindrops. As well, the higher concentration of tree roots near the base of the shade trees may have an effect on loosening the soil there by reducing soil bulk density. The higher BD outside the shade tree canopy is due to the soil dries out more, being exposed to direct sun light and making the soil more compact. 
Moreover, the higher BD outside the shade tree canopy could be attributed to increased soil compaction as a result of rain drop effect. This study finding agree with [15], who reported that significantly higher BD was observed outside the tree canopies than under the canopies of croton macrostachyus and Faidherbia albida in southern Ethiopia. This finding was also supported by $[16,17]$. On their study findings they were reported that lower BD under the canopies of Peltophorum africanum and Combretum apiculatum and under indigenous tree Canopies as compared to open area in Botswana and Eastern and Western Haragehe Zone respectively. However, in contrary to this study finding, the study results which was done in Badessa, Eastern Ethiopia showed that did not significant different was observed in bulk density under the canopies of Cordia africana and Croton macrostachyus as compared to outside the tree canopy [18].

\subsubsection{Soil Chemical Properties}

\section{(1) Soil $\mathrm{pH}$}

In this study finding, soil $\mathrm{pH}$ value was significantly affected by shade tree species and distance from the shade tree canopy. Under canopies of Ficus sur and Cordia africana shade tree species observed soil $\mathrm{pH}$ value was significantly higher $(\mathrm{P}<0.05)$ than outside the shade tree canopy. As shown in Table 3 below, the mean $\mathrm{pH}$ value under the canopies of Ficus sur and Cordia africana shade trees was 7.02 and 6.73 respectively. As compared to outside the shade tree canopy, the mean soil $\mathrm{pH}$ content under the canopies of Ficus sur and Cordia africana were decreased from 7.02 to 6.66 and 6.73 to 6.54 respectively. The main reason for higher soil $\mathrm{pH}$ value under the canopies of both coffee shade trees than outside the tree canopy might be attributable due to above ground litter fall deposition and decomposition of their below ground fine roots which have positive impacts on subsequent mineralization releases cations to the soil system. In line with this study finding, the study result which was done in Kenya showed that a significant difference in soil $\mathrm{pH}$ between the soils under the canopies of Prosopis juliflora and Acacia tortilis and outside the canopy of both treespecies [19]. However, in contrary to this study finding, there was no significant difference in soil $\mathrm{pH}$ was observed under the canopies of Millettia ferruginia, Cordia africana, Croton macrostachyus and Faidherbia albida as compared to outside the tree canopy [15, 18].

Table 3. Mean values of soil pH, CEC and SOC in the surface $(0-15 \mathrm{~cm})$ soils from under and away from the canopies of Ficus sur and Cordia africana coffee shade trees at Adola Rede District, in Guji Zone, Southern Ethiopia.

\begin{tabular}{|c|c|c|c|c|}
\hline \multirow{2}{*}{ Shade tree species } & \multirow{2}{*}{ Sample type } & pH & CEC & SOC \\
\hline & & Mean(Std) & Mean(Std) & Mean(Std) \\
\hline Ficus sur & Under canopy & $7.02^{\mathrm{a}} \pm 0.31$ & $44.26^{\mathrm{a}} \pm 14.65$ & $6.49^{\mathrm{a}} \pm 1.31$ \\
\hline Cordia africana & Under canopy & $6.73^{b} \pm 0.33$ & $25.86^{\mathrm{b}} \pm 7.53$ & $4.51^{b} \pm 1.15$ \\
\hline & Under canopy & $7.02^{\mathrm{a}} \pm 0.31$ & $44.26^{\mathrm{a}} \pm 14.65$ & $6.49^{\mathrm{a}} \pm 1.31$ \\
\hline Ficus sur & Open area & $6.66^{\mathrm{b}} \pm 0.37$ & $14.63^{b} \pm 0.48$ & $2.54^{\mathrm{b}} \pm 0.65$ \\
\hline & Under canopy & $6.73^{\mathrm{a}} \pm 0.33$ & $25.86^{\mathrm{a}} \pm 7.53$ & $4.51^{\mathrm{a}} \pm 1.15$ \\
\hline Cordia africana & Open area & $6.54^{\mathrm{b}} \pm 0.43$ & $15.85^{\mathrm{b}} \pm 5.97$ & $2.31^{\mathrm{b}} \pm 0.91$ \\
\hline
\end{tabular}

*Within column, soil parameters Means followed by the same letters are not significantly different.

*Within column, soil parameters Means followed by different letters are significantly different

(2) Cation Exchange Capacity (CEC)

The finding of this study showed that, CEC was significantly $(\mathrm{P}<0.05)$ influenced by coffee shade trees and distance from the shade tree canopy. The CEC under canopy of Ficus sur was significantly higher $(\mathrm{P}<0.05)$ than under canopy of Cordia africana (Table 3). This could be mainly due to more organic matter accumulation under canopy of Ficus sur than under canopy of Cordia africana. The CEC was significantly higher $(\mathrm{P}<0.05)$ in the soil under canopy of both shade trees as compared to outside the canopy area. This could be due to higher organic matter accumulation under canopy of both shade trees; more cations would be released to the soil through mineralization as a result the amount of CEC could be higher under canopy of both coffee shade trees The result coincides with the study findings which were done in Eastern and Southern Ethiopia on indigenous tree canopies and on scattered tree species respectively $[15,16]$. On their study findings they were reported that higher significant CEC increments were observed under tree canopy than in open area. However, in contrary to this study finding, the study results which were done in Eastern Ethiopia and In Sidama Zone Southern Ethiopia showed that CEC under the canopies of Millettia ferruginia, Croton macrostachyus and Cordia africana were not significantly higher than away from the tree canopy $[13,18]$.

(3) Soil Organic carbon

The SOC under canopies of both coffee shade trees were significantly higher $(\mathrm{P}<0.05)$ than outside the shade tree canopy. The SOC mean values under the canopies of Ficus sur and Cordia africana coffee shade tree species were $6.49 \mathrm{gm} / 100 \mathrm{gm}$ and $4.51 \mathrm{gm} / 100 \mathrm{gm}$ of soil respectively (Table 3). Based on interpretation of soil test results, if level of SOC is $3-8.7 \mathrm{gm} / 100 \mathrm{gm}$ of soil it is extremely higher SOC and the soil obviously have high level of organic matter [20]. The highest value of SOC under canopies of both coffee shade trees may have been caused from high organic matter accumulation due to increased above and below ground biomass under their canopies. The SOC under canopy of Ficus sur was significantly higher $(\mathrm{P}<0.05)$ than under canopy of Cordia africana. The higher SOC under canopy of Ficus sur may be due to fast decomposition of its litter fall and below ground decomposition of its fine roots. While the lower SOC under canopy of Cordia africana coffee shade tree may be due to slow decomposition of its leaf litter 
despite the heavy leaf fall as observed under its canopies.

Similar to this study finding, many authors also reported a higher level of SOC concentration under the canopies of different trees as compared to away from tree canopy. For instance, the study findings which were done in Northern Parts of Ethiopia in Alferom District, Tigray region and around Gondar showed that significantly higher content of SOC was observed under the canopy of Ficus thonningii as compared to soil beyond the canopy coverage [21, 22]. The finding of this study also supported with the study result which was done in Sidama, Southern Ethiopia [13]. On their study results indicated that, SOC under the canopies of Millettia ferruginia and Cordia africana were significantly higher than away from shade tree canopy. However, in contrary to this study result, in Bedesa, Eastern Ethiopia and in Bako area, Ethiopia the study findings which were done so far showed that SOC under the canopies of Cordia africana and Croton macrostachyus on farm trees were not significantly higher than outside the canopy area [11, 18]. They were indicated that, it could be attributed to the deep tillage and hoeing practices in the area that promote mixing of litter with soil and improvement of soil aeration that in turn promote the decomposition of litter resulting in less soil organic C.

(4) Total Nitrogen $\%$

As the finding of current study showed that, total $\mathrm{N}$ concentration under the canopies of both coffee shade trees were significantly higher $(\mathrm{P}<0.05)$ than away from the shade tree canopy. The mean total Nitrogen concentration under the canopies of Ficus sur and Cordia africana coffee shade trees was $0.67 \%$ and $0.49 \%$ respectively (Table 4 ). Based on analytical methods and interpretation of soil test results, if rating of total $\mathrm{N}$ is $0.25-0.5 \%$ and greater than $0.5 \%$ it is high and very high respectively [23]. Therefore, under canopy of Ficus sur and Cordia africana coffee shade tree species, observed mean values of total $\mathrm{N}$ could be very high and high respectively. This variation in total $\mathrm{N}$ as compared to outside the shade tree canopy zone of the present study is quite logical as the higher accumulation of organic matter under shade tree canopy due to their litter fall such as leaves, flowers and barks and decomposition of dead roots from coffee shade tree. As shown in Table 4 below, total Nitrogen under canopy of Ficus sur was significantly $(\mathrm{P}<0.05)$ higher than under the canopy of Cordia africana. The higher total Nitrogen under the canopy of Ficus sur might be due to more litter fall accumulation and fast decomposition ability of its litter fall. Similar to this study finding, the study results which were done in Central rift valley of Ethiopia and in Southern Ethiopia indicated that significantly higher total Nitrogen was observed under the canopies of Balanites aegyptiaca, Accacia tortolis, Accacia seyal, Faidherbia albida and Croton macrostachyus than outside the tree canopy $[14,15]$.

(5) Available Phosphorus

The amount of available phosphorus was highly significantly influenced by coffee shade tree species and distance from the tree canopy. Under canopies of both coffee shade trees, amount of available phosphorus were significantly higher $(\mathrm{P}<0.05)$ than outside the shade tree canopy (Table 4$)$. The higher level of available phosphorus under the canopies of both shade trees may have been caused by organic input from litter fall deposition and release at mineralization, higher microbial population stimulated by organic matter input which supported phosphorus solubilisation from fixation. As shown in Table 4 below, available phosphorus under the canopy of Ficussur was significantly higher $(\mathrm{P}<0.05)$ than under the canopy of Cordia africana coffee shade tree. This might be attributed to the high accumulation of organic matter under the canopy of Ficus sur coffee shade tree. In support of the present study, many research findings which were done in Central rift valley of Ethiopia, in eastern Ethiopia, in Southern Ethiopia and in arid southern Tunisia indicated that higher available phosphorus were observed under the tree canopies than in open area $[13,14,15,18,24]$. In contrary to this study finding, in Northern western Ethiopia under canopy of Croton macrostachyus lower available phosphorus was observed under the tree canopies than outside the tree canopy [25].

Table 4. Mean values of total $N$, available $P$ and exchangeable $K$ in the surface $(0-15 \mathrm{~cm})$ soils from under and away from canopy of Ficus sur and Cordia africana shade trees at Adola Rede District, in Guji zone, Southern Ethiopia.

\begin{tabular}{llll}
\hline \multirow{2}{*}{ Shade tree species } & Sample type & Total N \% & Available P \\
\cline { 2 - 4 } & Mean(Std) & Mean(Std) \\
\hline Ficus sur & Under canopy & $0.67^{\mathrm{a}} \pm 0.15$ & $7.52^{\mathrm{a}} \pm 1.87$ \\
Cordia africana & Under canopy & $0.49^{\mathrm{b}} \pm 0.09$ & $4.58^{\mathrm{b}} \pm 0.85$ \\
Ficus sur & Under canopy & $0.67^{\mathrm{a}} \pm 0.15$ & $7.52^{\mathrm{a}} \pm 1.87$ \\
& Open area & $0.41^{\mathrm{b}} \pm 0.12$ & $3.81^{\mathrm{b}} \pm 0.91$ \\
Cordia africana & Under canopy & $0.49^{\mathrm{a}} \pm 0.09$ & $4.07^{\mathrm{a}} \pm 0.95$ \\
& Open area & $0.42^{\mathrm{b}} \pm 0.07$ & $2.27^{\mathrm{a}} \pm 0.95$ \\
& & $2.50^{\mathrm{b}} \pm 0.85$ & $0.41^{\mathrm{b}} \pm 0.32$ \\
\hline
\end{tabular}

*Within column, soil parameters Means followed by the same letters are not significantly different.

*Within column, soil parameters Means followed by different letters are significantly different

(6) Exchangeable potassium

The amount of exchangeable potassium under the canopies of both coffee shade tree species were significantly higher $(p<0.05)$ than outside the tree canopy. It is due to the high accumulation of litter fall under the shade tree canopies as the cations could be released when the accumulated litters from the canopies of the trees undergo microbial decomposition followed by mineralization and release of simple products to the soil. Observed exchangeable potassium under canopy of Ficus sur shade tree was significantly higher $(\mathrm{p}<0.05)$ than under canopy of Cordia africana shade tree. The higher level of exchangeable 
potassium concentration under the canopy of Ficus sur could be due to higher organic matter deposition under shade tree canopy and increased biological activity which enhances organic matter decomposition and subsequent mineralization status. In line with this study finding, research results which was done in eastern Ethiopia showed that exchangeable $\mathrm{K}$ concentration under the canopy of Millettia ferruginia was significantly higher than outside the tree canopy [16].

\section{Conclusion}

Coffee growers' of the study District have ability to identify shade tree species used for soil fertility improvement. This is due to they have been working with agro-ecosystems for a long time, they have got rich agro-ecological knowledge and understanding of the functioning of these systems, based on hands-on experience and observations made over a long period. Based on their experience of growing coffee plants under canopy of different shade tree species, farmers' preference criteria of soil fertility improving shade tree species are mainly based on rate of litter fall decomposition, soil moisture status under their canopy, growing ability of coffee plants and increment of coffee yields under canopy of shade tree species. Accordingly, farmers' preferred coffee shade tree species such as Ficus sur, Cordia africana, Millettia ferruginia, Albizia gummifera, Croton macrostachyus and Acacia abyssinica for soil fertility enhancement respectively.

Based on farmers' preference ranking, soil samples were taken from under canopy of Ficus sur with $1^{\text {st }}$ rank and Cordia africana with $2^{\text {nd }}$ rank of soil fertility improving shade tree species. The study revealed that, both selected coffee shade tree species improve soil fertility and status of soil properties under canopy of Ficus sur and Cordia africana was significantly higher than outside the canopy area. Therefore, based on the finding of this study growing coffee plants under canopy of Ficus sur and Cordia africana shade tree species used to maintain soil fertility under coffee plants and paramount for coffee growers' to produce sustainable coffee production. Moreover, the soil laboratory analyzed results showed that soil physical and chemical properties under canopy of both Ficus sur and Cordia africana shade tree species are in agreement with farmers' rank of shade tree preferences. Therefore, if knowledge of local farmers is recorded and effectively used with scientific findings, it can provide valuable information that can feed back synergistically to channel the direction of conventional science to meet the needs of local people.

\section{Acknowledgements}

The authors express their gratitude to all staff members of Bore Agricultural Research Center for providing them with helpful advice and assisted them in data collection with patience, commitment and dedication. They are grateful to farmers of Adola Rede District who responded to all questions with patience and for making their fields available for soil sampling without posing any problem. Moreover, they are very grateful to the Oromia Agricultural Research Institute for its financial support.

\section{References}

[1] Ogunkunle, C., Awotoye, O. 2010. Soil Fertility Status under Different Tree Cropping System in a South western Zone of Nigeria Notulae Scientia Biologicae Avaliable at: www.notulaebiologicae.ro. Retrieved on August, 2011.

[2] Ranieri, S., Stirzaker, R., Suprayogo, D., Purwanto, E., Willigen, P., and Noordwijk, M. 2004. Managing movements of water, solutes and soil: from plot to landscape scale. Belowground Interactions in Tropical Agroecosystems.

[3] Christina, L. and Polzot, R. 2004. Carbon Storage in Coffee Agroecosystems of Southern Costa Rica: Potential Applications for the Clean Development Mechanism.

[4] Iben, N., Soren, L. and Theilade I. 2007. The Importance of Local Knowledge and Inter disciplinary Research. People, Trees and Agriculture in Africa: Constraints and Options for Improved Management of Trees in Tanzania and Burkina Faso. Journal of Trans disciplinary Environmental Studies, vol. 6, no. 1 .

[5] Allen, S. C. 2004. Safety-net role of tree roots: evidence from a pecan (Caryaillinoensis K. Koch)-cotton (Gossypium hirsutum L.) alley cropping system in the southern United States. Journal of Forest Ecology and Management, Vol 192, pp 395-407.

[6] Blair, J. M., Parmelee, R. W. and Beare, M. H. 1990. Decayrates, nitrogen fluxes, and decomposer communities of singlespecies and mixed-species foliar litter. Journal of Ecology, 71, 1976-1985.

[7] Haggar, J., Tanner, E., Beer, J., and Kass, D. 1993. Nitrogen dynamics of tropical agroforestry and annual cropping systems. Journal of Soil Biology and Biochemical, Vol. 25, pp1363-1378.

[8] Beer, J., Muschler, R., Kass, D. and Somarriba, E. 1998. Shade management in coffee and cacao plantations. Journal of Agroforestry Systems, Vol 38, pp139-164.

[9] Yazachew, E. and Kasahun, D. 2011. The National regional government of Oromia, Physical and socio economic profile of Guji zone districts'.

[10] Central Statistics Agency (CSA). 2008. Summary and Statistical Report of the 2007 Population and Housing Census. Population size by age and sex. Federal Democratic Republic of Ethiopia Population Census Commission, Addis Ababa, Ethiopia.

[11] Abebe, Y., Fisseha, I. and Olsson, M. 2009. Scattered trees as modifiers of agricultural landscapes: the role of Waddeessa (Cordia africana Lam.) trees in Bako area, Oromia, Ethiopia. Afr. J. Eco. (47-suppl. 1), 78-83.

[12] Zebene, A. 2008. Growth of Millettia ferruginia and its impact on soil properties of three Coffee plantations of southern Ethiopia. Ethiopian Journal of Natural Resources, Vol. 10 (2): 147-16.

[13] Zebene, A. and Agren. G. 2007. Farmers' local knowledge and top soil properties of agroforestry practices in Sidama, southern Ethiopia. Journal of Agroforest system, Vol. 71:35-48. 
[14] Agena, A, Tilahun, F. and Bekele, L. 2014. Effects of three tree species on microclimate and soil amelioration in the central rift valley of Ethiopia, Journal of Soil science and Environmental Management, Vol. 5(5), PP. 62-71.

[15] Belay, M., Tesfaye, A. and Abdu, A. 2014. Effects of scattered F. albida (Del) and C. macrostachyus (Lam) tree species on key soil physicochemical properties and grain yield of Maize (Zea Mays): a case study at UmbuloWacho watershed, southern Ethiopia. Wudpecker Journal of Agricultural Research, Vol. 3(3), pp. $063-07$.

[16] Abebe, N. 2006. Soil Fertility Status under Indigenous Tree Canopies on Farm land in Selected Areas of Eastern and Western Haragehe Zone. M.Sc. Thesis. Haramaya University, Haramaya.

[17] Aweto, A. O. and Dikinya, O. 2003. The beneficial effects of two tree species on soil properties in a semi-arid savanna range land in Botswana. Journal of Land Contamination and Reclamation, Vol 11(3), pp 339-334.

[18] Jiregna, G., Andrey, R. and Legesse, N. 2005. Trees on farms and their contribution to soil fertility parameters in Badessa, Eastern Ethiopia, Journal of BiolFertil Soils, Vol. 42, pp 6671.

[19] Kahi, C. H., Ngugi, R. K., Mureithi, S. M. and Ng'ethe, J. C. 2009. The canopy effects of Prosopis juliflora (DC.) and Acacia tortilis (HAYNE) trees on herbaceous plant species and soil physico- chemical properties in Njemps flats, Kenya. Journal of Tropical and Subtropical Agroecosystems, Vol. 10, PP. 441-449.

[20] Pam, H. and Brian, M. 2007. Interpretation of soil test results, Csiro Publishing, Australia.

[21] Daniel, H. 2011. Evaluation on the biomass production and fodder quality of Ficus thonningii (BLUME) and its effects on soil physico-chemical properties, in Alferom District, Tigray, Ethiopia, MSc Thesis, Wondo Genet College of Forestry and Natural resources, Hawassa University.

[22] Enideg, D. 2008. Importance of Ficus thonningii(Blume) in Soil Fertility improvement and animal nutrition in Gondar Zuria, Ethiopia, M.Sc. Thesis, University of Natural Resources and Applied Life Science, Vienna.

[23] Bruce, R. C. and Rayment, G. E. 1982. Analytical methods and interpretations used by the Agricultural Chemistry Branch for Soil and Land Use Surveys.

[24] Jeddi, K., Cortina, J. and Chaieb, M. 2013. Acacia salicina, Pinus halepensis and Eucalyptus occidentalis improve soil surface conditions in arid southern Tunisia, Journal of Arid Environments, 73 (2009) 1005-1013.

[25] Yeshanew, A., Mats, O. and Tekalign, M. 1998. Contribution of Croton macrostachys to Soil Fertility in Maize-Based Subsistence Agriculture of Bure Area, North Western Ethiopia. Proc. 6th ESA maize conference. pp 232-234. 